\title{
PENERAPAN ASUHAN KEPERAWATAN PADA PASIEN TUBERKULOSIS PARU DALAM PEMENUHAN KEBUTUHAN NUTRISI DI RSUD LABUANG BAJI MAKASSAR
}

\section{The Application Of Nursing Care To Patients With Pulmonary Tuberkulosis Paru In Meeting Nutritional Needs In The Labuang Baji Makassar Wedge Hospital}

\author{
Nurlina, Hamsinah \\ Prodi DIII Keperawatan Universitas Muhammadiyah Makassar \\ Email: nurlinajamal@gmail.com \\ HP : 081260674014
}

\begin{abstract}
Introduction: Tuberculosis is a bactericidal infection caused by Microbacterium Tuberkulosis and is characterized by the formation of glanuloma in infected tissue and by hypersensitivity in the cell parenteria. According World Health Organizatoin (WHO) data in 2018 it is estimated that there are 10.4 million cases of pulmonary TB studies throughout the world, and 10 million people are children. Indonesia is included in 7 countries that countributed $64 \%$ of new cases in the world and became second only to India with the highesst pulmonary TB sufferer inthe world. Objective : to know the application of nursing care to patients with pulmonary Tuberculosis in meeting nutritional needs. Method : this study uses interview and observation methods. Results : after of nursing actions were carried out for patients, the nutrition problem was overcome based on shortterm goals by Criteria : the client spent food and the client was not weak. Conclusion : based on the above data it can be concluded that the client problem is resolved. Suggestion : Expected to nurses in carrying out the assesment of the client, collecting data using therapeutic communication so that there is a trusing relationship with the patient and the patient's family, both by using interview techniques, observation, physical examination to gather information that can be used to establish nursing diagnoses.
\end{abstract}

Keywords : Nursing Care: Nutrition Requirement; Pulmonary Tuberculosis,.

Abstrak

Pendahuluan: Tuberkulosis adalah infeksi bakteri kronik yang di sebabkan oleh microbakterium tuberculosis dan ditandai oleh pembentukan glanuloma pada jaringan yang terinfeksi dan oleh hipersensivitas yang di parenterai sel. Menurut data World Health Organization (WHO) tahun 2018 di perkirakan ada 10,4 juta kasus studi TB Paru diseluruh dunia, dan 1,7 juta meninggal karena penyakit TB Paru, dimana 6,2 juta sejumlah laki-laki 3,2 juta adalah perempuan dan 10 juta orang merupakan anak-anak. Indonesia termaksud dalam 7 Negara yang penyumbang $64 \%$ dari kasus-kasus baru didunia dan menjadi urutan kedua setelah india dengan penderita TB Paru Tertinggi di dunia. Tujuan: mengetahui penerapan asuhan keperawatan pada pasien Tuberkolosis Paru dalam pemenuhuan kebutuhan nutrisi. Metode: Penelitian ini menggunakan metode wawancara dan observasi. Hasil: Setelah di lakulan tindakan keperawatan pada pasien maka masalah nutrisi teratasi berdasarkan tujuan jangka pendek dengan Kriteria: klien menghabiskan makanan dan klien tidak lemas. Kesimpulan: berdasarkan data di atas dapat di simpulkan bahwa masalah klien teratasi. Saran: Diharapkan kepada perawat dalam melaksanakan pengkajian pada klien, mengumpulkan data dengan menggunakan komunikasi terapeutik agar terbina hubungan saling percaya dengan pasien maupun keluarga pasien, baik dengan menggunakan teknik wawancara, observasi, pemeriksaan fisik untuk mengumpulkan informasi yang dapat digunakan untuk menegakkan diagnosa keperawatan.

Kata kunci ; Asuhan Keperawatan: Kebutuhan Nutrisi: Tuberculosis Paru

\section{PENDAHULUAN}

Tuberkulosis adalah infeksi bakterikronik yang disebabkan oleh Micobakterium Tuberculosis dan ditandai oleh pembentukan glanuloma pada jaringan yang terinfeksi dan oleh hipersensitivitas yang di parenterai sel. (Wahid \& Suprapto, 2013) Menurut data World Health Organization (WHO) tahun 2018 di perkirakan ada 10,4 juta kasus TB Paru di seluruh dunia, dan 1,7 juta meninggal karena penyakit TB Paru, dimana 6,2 juta sejumlah laki-laki 3,2 juta adalah perempuan dan 1 juta orang merupakan anak-anak. Indonesia termasuk dalam tujuh negara yang penyumbang $64 \%$ dari kasuskasus baru di dunia dan menjadi urutan kedua setelah india dengan penderita TB Paru tertinggi di dunia. Secara global, angka kematian TB Paru mengalami penurunan sebesar $37 \%$ antara tahun 2000 dan 2016.

Berdasarkan data Riskesdas (2018), prevelensi TB Paru di indonesia tidak mengalami perubahan dari tahun 2013 sampai tahun 2018, yaitu menetap pada angka $0,4 \%$.

Dan hasil penelitian yang dilakukan Putri (2016), di Makassar mengenai status gizi pasien TB Paru yang dinilai berdasarkan hasil pengukuran Indeks Massa Tubuh (IMT) didapatkan sebanyak 51,3 $\%$ penderita TB Paru memiliki gizi kurang. Data lingkar lengan atas (LLA) sebanyak $41,7 \%$ orang 
penderita TB Paru yang memiliki LLA $<21 \mathrm{~cm}$ artinya mengalami malnutrisi. Data Malnutrition Universal Screening Tools (MUST) sebnayak $86,1 \%$ orang memiliki skor MUST >2 artinya berisiko tinggi mengalami malnutrisi. (Putri, Munir, \& Cristianto, 2016)

Tingkat penyembuhan dan kesakitan TB Paru sangat tinggi, komplikasi yang dapat terjadi berupa batuk darah masif, keadaan umum buruk, pneumonia thoraks, epiema, efusi pleura dan sesak nafas berat. Buruknya penderita TB Paru dapat mempengaruhi status gizi sehingga terjadi malnutrisi. (Putri,Munir,\& Christianto. 2016)

Salah satu faktor yang mempengaruhi terjangkitnya penyakit Tuberkulosis Paru adalah status gizi. Status gizi yang buruk akan meningkatkan risiko penyakit tuberkulosis paru. Sebailiknya, Tuberkulosis Paru berdistribusi menyebabkan status gizi buruk karena proses perjalanan penyakit yang mempengaruhi daya tahan tubuh. Masalah gizi menjadi penting karena perbaikan gizi merupakan salah satu upaya untuk memutus lingkaran penularan dan pemberantasan Tuberkulosis di Indonesia. (Wartonah T. , 2015)

Penanganan malnutrisi pada pasien TB Paru melibatkan banyak unsur termasuk didalamnya perawat yang berperan sebagai fasilitas perawatan kesehatan, dalam mengoptimalkan pengelolaan nutrisi pada Tuberkulosis Paru yang mengalami nafsu makan menurun, malabsorbsi nutrisi, dan metabolisme yang berlebihan sehinga terjadi proses penurunan massa otot dan lemak sebagai manifestasi malnutrisi. Oleh karena itu penulis akan melakukan studi kasus tentang penerapan asuhan keperawatan pada pasien Tuberkulosis Paru dalam pemenuhan kebutuhan nutrisi untuk dapat membantu penderita Tuberkulosis Paru untuk mencapai kesembuhan yang optimal. Tujuan penelitian adalah mengetahui penerapan asuhan keperawatan pada pasien Tuberkulosis Paru dalam pemenuhan kebutuhan nutrisi?

\section{BAHAN/METODE}

Desain Penelitian

Rancangan penelitian ini menggunakan metode Studi kasus dengan melakukan wawancara dan observasi yang meliputi penerapan Asuhan Keperawatan pada Pasienn TB Paru dalam Pemenuhan Kebutuhan Nutrisi.

\section{Lokasi dan Waktu}

Tempat peleksanaan studi kasus di Ruang Perawatan Baji Ati RSUD Labuang Baji Makassar, dilaksanakan pada bulan Juni 2019

\section{Populasi, Sampel dan Sampling}

Subyek studi kasus yang akan dikaji adalah satu pasien dengan Tuberkulosis Paru yang mengalami gangguan pemenuhan kebutuhan nutrisi

Cara Pengumpulan Data
Agar data dapat terkumpul dengan baik dan terarah, dilakukan pengumpulan data dengan metode wawancara (mengkaji data-data pasien) dan observasi terhadap pelaksanaan asuhan keperawatan pada subjek

\section{Pengolahan dan Analisis Data}

Data yang telah terkumpul selama proses pengumpulan data disajikan dalam bentuk tekstural yang bersifat naratif dan disertai dengan cuplikan ungkapan verbal dari subjek studi untuk dijadikan sebagai data pendukung.

HASIL

Pengkajian

Pengkajian dilakukan di ruang Baji Ati RSUD Labuang Baji dari pengkajian tersebut didapatkan data sebagai berikut: Klien mengatakan makan sedikit, Klien terpasang infus RL 20 tpm, keadaan umum lemah.Riwayat batuk lama, klien mengatakan nyeri dada yang di alami sejak 2 minggu yang lalu. Riwayat batuk lama pernah mengomsumsi OAT selama 2 minggu yang lalu. Klien mengatakan mual dan muntah. Keluhan nutrisi klien, klien mengatakan hanya makan 4 sendok/hari dalam satu porsi, klien mengatakan pusing saat bangun dari tempat tidurnya, klien terlihat nampak kurus. Riwayat kesehatan dahulu Klien pernah sakit tipes dan ternyata ada cairan di paru-paru, klien mengatakan menderita penyakit tipes kurang lebih 1 bulan, keluarga klien mengatakan pernah di rawat di puskesmas, selama 1 minggu klien mengatakan tidak pernah mengalami kontak dengan penderita TB Paru. Riwayat kesehatan keluarga: tidak ada keluarga yang menderita TB Paru, tidak ada anggota keluarga klien yang merokok. Keluhan nutrisi klien, klien mengatakan mual dan muntah, klien mengatakan Jenis makanan klien bubur, telur, sayur, dengan frekuensi makan 2 kali sehari. Pemeriksaan fisik di dapatkan data: keadaan umum klien lemah, berat badan klien saat pengkajian $37 \mathrm{Kg}$ dan tinggi badan $164 \mathrm{~cm}$. Pemeriksaan tanda-tanda vital di dapatkan hasil Tekanan darah : 120/80 mmHg, Nadi: $84 x / m$, Pernafasan $18 x / m$, Suhu: $36,2^{0} \mathrm{C}$. klien mengalami penurunan berat badan dari $39 \mathrm{Kg}$ menjadi $37 \mathrm{Kg}$. Konjungtiva nampak merah muda (hemoglobin 13,2 g/dl) mukosa bibir pucat, keadaan kuku mudah patah dan agak kotor. Keadaan rambut kusam, kering dan mudah patah. Kulit nampak kering dan pucat. Berat badan Ideal (164$100)-(10 \% x(164-100)=64-(10 \% \times 64)=64 \quad 6,4=57,6 \mathrm{~kg}$. Maka berat badan ideal pria dengan tinggi $164 \mathrm{~cm}$ adalah $57,6 \mathrm{~kg}$. IMT= 39/1,64x1,64 = 39/2,68 = 14,5 (Normal 18,5-25,0). LILA Lipatan kulit triseps (mm) tidak di ukur (Normal 12,5), Lingkar lengan atas (cm) $16 \mathrm{~cm}$ (Normal 29,3), Lingkar otot lengan tengah (cm) $20 \mathrm{~cm}$ (Normal 25,3). Pemeriksaan penunjang : thoraks : (+) karena TB Paru aktif pada tanggal 10 Juni 2019. kultur sputum BTA (-), pada tanggal 11 Juni 2019. Leukosit (WBC)10,1, Eritrosit (RBC) 5,02, 
Hemoglobin (HGB) 13,2(Normal 14-18), Hemotokrit (HCT) 39,8, Trombosit(PLT) 421, Limfosit 13,8, GDS 93 (Normal $<=200$ ) Urea (BUN) 14 (Normal 23-43), Kreatinin 0,59 (Normal 0,8-1,4), SGOT 13 (10-40), SGPT 6 (Normal 10-55). Terapi obat yang didapatkan : infuse RL 20 tpm/IV, injeksi methilprednisolon amp/IV $2 \times 1$, injeksi ranitidin /12 jam/IV, codein $20 \mathrm{mg} /$ oral $3 \times 1$, betahistine mesylate/oral $2 \times 1$, sucralfate suspensi $3 \times 1$, OAT (rifamfisin $150 \mathrm{mg}$, isoniazid $75 \mathrm{mg}$, pyrazinamide 400 $\mathrm{mg}$, ethambutol hydrochloride $270 \mathrm{mg}$ ).

\section{Diagnosa keperawatan}

Berdasarkan hasil pengkajian tersebut diatas maka dirumuskan Diagnosa Keperawatan yaitu: Nutrisi kurang dari kebutuhan tubuh berhubungan dengan intake yang tidak adekuat. Data subjektif: klien mengatakan tidak ada nafsu makan dan hanya makan 4 sendok dalam satu porsi dengan jenis makanan bubur, telur, sayur, dengan frekuensi makan klien 2 kali sehari sebelum dikaji. Klien mengatakan sering merasa mual dan muntah klien memiliki riwayat tipes selama satu bulan dan pernah di rawat di puskesmas selama 1 minggu. Klien mengatakan sangat lemah dan pusing saat bangun dari tempat tidur. Data objektif: klien nampak lemah hanya bisa berbaring, keadaan rambut klien kering, kusam, dan mudah patah, mata nampak anemis (hemoglobin 13,2), mukosa bibir pucat, kuku klien mudah patah dan pucat. Klien hanya makan memakan 4 sendok dari porsi makannya. Berat badan klien saat sakit $37 \mathrm{~kg}$ dan tinggi badan $164 \mathrm{~cm}$. Hasil pemeriksaan TTV klien yaitu: tekanan darah: 120/80 mmHg, nadi: $84 \mathrm{x} / \mathrm{menit}$, suhu: $36^{0} \mathrm{C}$, dan pernapasan : $18 \mathrm{x} /$ menit.

\section{Intervensi keperawatan}

Intervensi keperawatan yang akan dibahas adalah rencana keperawatan yang sesuai dengan prioritas masalah pada klien, yaitu Nutrisi kurang dari kebutuhan tubuh berhubungan dengan intake yang tidak adekuat. Adapun tujuan dari intervensi keperawatan yang ingin dicapai adalah setelah dilakukan tindakan keperawatan selama 4 hari, diharapkan kebutuhan nutrisi pasien terpenuhi, dengan kriteria hasil: pasien mengungkapkan tidak ada mual dan nafsu makan baik, intake makanan sesuai dengan kebutuhan tubuh.

Intervensi yang dibuat berdasarkan diagnosa keperawatan adalah:

a. Kaji status nutrisi klien, bagaimana turgor kulitnya, kemampuan menelan, integritas mukosa oral.

Rasional: memvalidasi dan menetapkan derajat masalah untuk menetapkan intervensi yang tepat.

b. Kaji tanda-tanda vital

Rasional mengetahui keadaan umum pasien.

c. Kaji pola makan klien

Rasional : mengidentifikasi kebutuhan nutrisi khusus untuk pasien.

d. Timbang berat badan

Rasional: berguna untuk mengukur keefektivan nutrisi.

e. Anjurkan pasien makan sedikit tapi sering

Rasional : makan sedikit tapi sering dapat membantu mengendalikan energi dan pemenuhan nutrisi.

f. Anjurkan perawatan mulut sebelum makan atau sesudah makan

Rasional: menurunkan rasa tidak enak karena sisa makanan, sisa sputum atau obat pada pengobatan sistem pernafasan yang dapat merangsang pusat muntah.

g. Jelaskan pentingnya masukan nutrisi

Rasional: proses penyembuhan memerlukan masukan cukup TKTP.

h. Kolaborasi dengan ahli gizi untuk menetapkan komposisi dan jenis diet yang tepat

Rasional: merencanakan diet dengan kandungan gizi yang cukup untuk memenuhi peningkatan kebutuhan energi dan kalori sehubungan dengan status hipermetabolik klien.

i. Kolaborasi dengan tim medis untuk memberikan terapi mulvtamin

Rasional: pengobatan yang tidak terpisahkan dari peningkatan status nutrisi klien.

j. Berikan dukungan kepada pasien jika dia mampu melakukan program nutrisi dengan benar

Rasional: memberikan motivasi dan kepercayaan diri pada klien untuk tetap melakukan diet.

\section{Implementasi keperawatan}

Berdasarkan intervensi keperawatan dari prioritas masalah yang muncul, adapun implementasi sebagai berikut :

\section{Pada hari Selasa Tanggal 11 Juni 2019}

Mengkaji status nutrisi: mengkaji turgor kulitnya, integritas mukosa oral, kemampuan menelan. Dengan hasil: turgor kulit kering dan pucat, integritas mukosa oral tampak pucat, kemampuan menelan klien tidak baik karena rasa pahit di lidah pada saat menelan. Dilanjutkan dengan mengkaji tanda-tanda vital klien, Hasil : Td: 120/80 mmHg, N: $80 \mathrm{x} / \mathrm{m}, \mathrm{S}: 36^{0} \mathrm{C}, \mathrm{P}: 18 \mathrm{x} / \mathrm{m}$. Mengkaji pola makan klien dengan hasil: klien makan $2 x /$ hari dengan menu bubur, sayur, telur, dan buah pisang, serta porsi yang dihabiskan 4 sendok/hari dalam satu hari, Menimbang berat badan Hasil : BB klien saat di timbang $37 \mathrm{~kg}$. Implementasi lainnya adalah menganjurkan klien makan sedikit tapi sering, mengajarkan klien merawat mulut sebelum makan dan sesudah makan dan menjelaskan pentingnya masukan nutrisi serta memberikan dukungan kepada klien jika dia mampu melakukan program nutrisi dengan baik 


Tindakan kolaborasi
mengkolaborasikan dengan ahli gizi untuk
menetapkan komposisi dan jenis diet yang tepat

\section{Pada hari Rabu Tanggal 12 Juni 2019}

Tindakan keperawatan pada hari kedua masih sama seperti hari pertama. Sudah ada beberapa perubahan pada hasil yang ditemukan pada hari kedua antara lain: Hasil Tanda-tanda vital TD: $110 / 70 \mathrm{mmHg}$, $\mathrm{N}: 80 \mathrm{x} / \mathrm{m}, \mathrm{S}: 36,6^{0} \mathrm{C}, \mathrm{P}: 20 \mathrm{x} / \mathrm{m}$. klien makan dengan menu bubur, sayur sup, ikan, dengan porsi yang dihabiskan 4 sendok makan 3x/hari. Berat badan masih sama pada hari pertama.

Tindakan kolaborasi dengan ahli Gizi tentang jenis diet yang tepat dan diberikan makanan dengan komposisi Energi $2.300 \mathrm{kkal}$, protein 86 gram, lemak 51 gram, karbohidrat 373 gram dengan jenis Diet TKTP (Tinggi Kalori Tinggi Protein). Kolaborasi lainnya adalah pemberian terapi multivitamin dengan pemberian Vitamin $\mathrm{C}$ oral $3 \times 1$

\section{Pada hari Kamis Tanggal 13 Juni 2019}

Tindakan keperawatan hari ketiga masih sama dengan Tindakan keperawatan hari kedua antara lain: Mengkaji status nutrisi klien bagaimana turgor kulitnya, integritas kulit oral, kemampuan menelan dengan hasil turgor kulit klien abnormal, integritas mukosa bibir pucat, kemampuan menelan klien normal. Mengkaji tanda-tanda vital klien dengan hasil Td: $130 / 80 \mathrm{mmHg}, \mathrm{N}: 84 \mathrm{x} / \mathrm{m}, \mathrm{S}: 36^{\circ} \mathrm{C}, \mathrm{P}: 20 \mathrm{x} / \mathrm{m}$. Mengkaji pola makan dengan hasil klien makan $3 x / h a r i$ dengan menu bubur, sayur wortel dan buncis, tempe, dan pisang. Serta dihabiskan 4 sendok makan. Menimbang Berat badan dengan hasil BB klien saat ditimbang $37 \mathrm{~kg}$. Menganjurkan klien makan sedikit tapi sering, hasil klien mengatakan sudah melakukan makan sedikit tapi sering dalam jumlah 5 sendok makan. mengajarkan klien merawat mulut sebelum makan dan sesudah makan dengan hasil klien mengatakan hari ini sudah membersihkan mulutnya sebelum makan dan setelah makan. Menjelaskan pentingnya masukan nutrisi dengan hasil klien dan keluarga mengatakan sudah mengerti pentingnya masukan nutrisi yang baik untuk tubuh.

Tindakan kolaborasi adalah mengkolaborasikan dengan ahli gizi untuk menetapkan komposisi dan jenis diet yang tepat, Adapun diet yang diberikan dengan komposisi makan yang diberikan yaitu: Energi 2.300 kkal, Protein 86 gram, Lemak 51 gram, Karbohidrat : 373 gram. Jenis diet TKTP (Tinggi Kalori Tinggi Protein). Dan mengkolaborasikan dengan tim medis untuk memberikan terapi multivitamin yaitu pemberian obat Vitamin C Oral $3 \times 1$. Klien mengatakan setelah diberikan obat multivitaamin klien belum merasakan ada perubahan.

Tindakan terakhir adalah memberikan dukungan kepada pasien jika dia mampu melakukan program nutrisi dengan baik, hasilnya adalah klien nampak mengerti dengan dukungan yang diberikan karena dia memiliki semnagat untuk melakukan program diet yang diberikan.

\section{Hari Jum'at Tanggal 14 Juni 2019}

Tindakan keperawatan hari terakhir adalah mengkaji status nutrisi klien bagaimana turgor kulitnya, integritas mukosa oral, kemampuan menelan dengan hasil turgor kulit klien abnormal, integritas mukosa oral pucat, kemampuan menelan klien normal. Mengkaji tanda-tanda vital klien, hasil: Td: $110 / 80 \mathrm{mmHg}, \mathrm{N}: 80 \mathrm{x} / \mathrm{m}, \mathrm{S}: 37^{0} \mathrm{C}, \mathrm{P}: 18 \mathrm{x} / \mathrm{m}$. Mengkaji pola makan klien dengan hasil klien makan $3 \times 1 /$ hari dengan menu bubur, sayur sup, wortel, daging ayam, dan pisang. Serta yang dihabiskan 1 porsi. Dan Menimbang Berat badan dengan hasil BB saat ditimbang $37 \mathrm{~kg}$.

Tindakan keperawatan lainnya adalah mengajurkan klien makan sedikit tapi sering dengan hasil klien mengatakan sudah mau makan sedikit tapi sering dengan jumlah 4 sendok makan dalam 3x/hari. Mengajarkan klien merawat mulut sebelum makan dan sesudah makan dengan hasil klien mengatakan merasa nyaman setelah membersihkan mulut secara rutin. Menjelaskan pentingnya masukan nutrsi, hasilnya adalah klien dan keluarga nampak mengerti dengan pentingnya masukan nutrisi karena dia sudah mendukung klien untuk menjalankan program dietnya.

Tindakan kolaborasi adalah mengkolaborasikan dengan ahli gizi untuk menerapkan komposisi dan jenis diet yang tepat sehingga ahli gizi menetapkan makan yang diberikan yaitu Energi 2.300 kkal, Protein 86, Lemak $51 \mathrm{gram}$, Karbohidrat $373 \mathrm{gram}$. Jenis diet TKTP (Tinggi Kalori Tinggi Protein). Serta mengkolaborasikan dengan tim medis untuk memberikan terapi multivitamin sehingga diberikan obat Vitamin C Oral 3x1. Klien mengatakan nafsu makannya sudah mulai membaik.

Tindakan lainnya adalah memberikan dukungan kepada pasien jika dia mampu melakukan program nutrisi dengan baik dengan hasil klien nampak melakukan program nutrisi dengan baik dan tepat.

\section{Evaluasi keperawatan}

Evaluasi dilakukan dengan metode SOAP yaitu S: Subjek (klien mengatakan), O: Objektif (klien terlihat/hasil temuan perawat) A: Assesment (Apakah masalah teratasi atau belum), P: Planning (Intervensi di lanjutkan atau dihentikan).

\section{Pada Hari Selasa 11 Juni 2019 Pukul 13:15 WITA}

Data subjektif : klien mengatakan masih sulit menelan karena masih terasa pahit di lidah klien saat menelan, klien mengatakan nafsu makannya 
belum membaik, klien mengatakan mengalami mual muntah, klien mengatakan sudah melakukan makan sedikit tapi sering dengan jumlah 4 sendok dalam 3x/hari.

Data objektif : klien nampak meringis saat menelan makanan, klien tidak menghabiskan porsi makannya, klien nampak lemas, TTV klien TD: 120/80 mmHg, $\mathrm{N}$ : $80 \mathrm{x} / \mathrm{m}, \mathrm{S}: 36^{0} \mathrm{C}, \mathrm{P}: 18 \mathrm{x} / \mathrm{m}$. Assesment : Masalah tidak teratasi. Planning : Lanjutkan intervensi (1) kaji nutrisi klien (2) kaji tanda-tanda vital (3) kaji pola makan (4) timbang berat badan (5) anjurkan klien makan sedikit tapi sering (6) ajarkan perawatan mulut sebelum makan dan sesudah makan (7) jellaskan pentingnya masukan nutrisi (8) kolaborasikan dengan ahli gizi untuk menetapkan komposisi diet yang tepat (9) kolaborasikan dengan tim medis pemberian obat multivitamin (10) berikan dukungan kepeda klien jika dia mampu melakukan program nutrisi dengan benar.

\section{Pada hari Rabu 12 Juni 2019}

Pukul 12:30 WITA

Data subjektif : klien mengatakan masih sulit menelan karna rasa pahit di lidah klien saat menelan, klien mengatakan nafsu makan sudah mulai ada, klien mengatakan sudah melakukan makan sedikit tapi sering dalam jumlah 4 sendok makan dalam $3 x /$ hari, klien mengatakan sudah mulai belajar membersihkan mulutnya.

Data objektif : klien masih nampak meringis saat menelan makanan, klien nampak sudah mulai menambah frekuensi makannya, klien nampak sudah mulai bersemangat dan percaya diri, TTV TD: $110 / 80 \mathrm{mmHg}, \mathrm{N}: 80 \mathrm{x} / \mathrm{m}, \mathrm{S}: 36,6^{0} \mathrm{C}, \mathrm{P}$ : 20x/m.

Assesment : Masalah tidak teratasi, Planning: lanjutkan intervensi (1) kaji status nutrisi klien (2) kaji tanda-tanda vital klien (3) kaji pola makan klien (4) timbang berat badan (5) anjurkan klien makan sedikit tapi sering (6) ajarkan perawatan mulut sebelum makan dan sesudah makan (7) jelaskan pentingnya masukan nutrisi (8) kolaborasikan dengan ahli gizi untuk menetapkan komposisi diet yang tepat (9) kolaborasikan dengan tim medis pemberian obat multivitamin (10) berikan dukungan kepada klien jika dia mampu melakukan program nutrisi dengan benar.

\section{Pada hari Kamis 13 Juni 2019}

\section{Pukul 11:00 WITA}

Data subjektif: klien mengatakan sudah tidak sulit menelan, klien mengatakan nafsu makan mulai bertambah, klien mengatakan sudah tidak mual muntah lagi, klien mengatakan sudah menghabiskan $1 / 2$ porsi makannya, klien mengatakan sudah melakukan makan sedikit tapi sering dengan jumlah 4 sendok dalam 3x/hari, klien mengatakan sudah membersihkan mulutnya. Data objektif : klien nampak tidak meringis lagi, klien nampak menghabiskan 1/2 porsi makannya, klien tidak lemas lagi, klien sudah mampu melakukan makan sedikit tapi sering, klien nampak membersihkan mulutnya, TTV TD:120/80mmHg, $\mathrm{N}: 78 \mathrm{x} / \mathrm{m}, \mathrm{S}: 36^{0} \mathrm{C}, \quad \mathrm{P}: 18 \mathrm{x} / \mathrm{m}$.

Assesment : masalah teratasi, Planning : pertahankan intervensi (1) kaji status nutrisi klien (2) kaji tanda- tanda vital klien (3) kaji pola makan klien (4) timbang berat badan (5) anjurkan klien makan sedikit tapi sering (6) ajarkan perawatan mulut sebelum makan dan sesudah makan (7) jelaskan pentingnya masukan nutrisi (8) kolaborasikan dengan ahli gizi untuk menetapkan komposisi diet yang tepat (9) kolaborasikan dengan tim medis pemberian obat multivitamin (10) berikan dukungan kepada klien jika dia mampu melakukan program nutrisi yang benar.

Pada hari Jum'at Tanggal 14 Juni 2019 Pukul 13:30 WITA

Data subjektif : klien mengatakan sudah tidak sulit menelan, klien mengatakan nafsu makan sudah mulai membaik, klien mengatakan sudah hampir menghabiskan porsi makannya, klien mengatakan sudah melakukan makan sering tapi sedikit dengan jumlah 4 sendok dalam 3x/hari, klien mengatakan sudah membersihkan mulutnya sebelum dan sesudah makan.

Data objektif : klien nampak tidak meringis lagi, klien nampak hampir menghabiskan porsi makannya, klien tidak lemas lagi, klien sudah tidak mampu melakukan makan sedikit tapi sering, klien nampak membersihkan mulutnya. TTV Td: $120 / 80 \mathrm{mmHg}, \mathrm{N}: 80 \mathrm{x} / \mathrm{m}, \mathrm{S}: 36,6^{0} \mathrm{C}$, P: $20 \mathrm{x} / \mathrm{m}$. Assesment : Masalah teratasi, planning : pertahankan intervensi (1) kaji status nutrisi klien (2) kaji tandatanda vital klien (3) kaji pola makan klien (4) timbang berat badan (5) anjurkan klien makan sedikit tapi sering (6) ajarkan perawatan mulut sebelum makan dan sesudah makan (7) jelaskan pentingnya masukan nutrisi (8) kolaborasikan dengan ahli gizi untuk menetapkan komposisi diet yang tepat (9) kolaborasikan dengan tim medis pemberian obat multivitamin (10) berikan dukungan kepada klien jika dia mampu melakukan program nutrisi yang benar.

\section{PEMBAHASAN}

Berdasarkan laporan kasus Asuhan Keperawatan yang dilaksanakan pada klien $\mathrm{Tn}$. M dengan diagnosa medis Tuberkulosis Paru di Ruang Baji Ati di RSUD Labuang Baji Makassar. Maka pada bagian ini penulis akan membahas hasil pelaksanaan studi kasus.

\section{Pengkajian}

Berdasarkan hasil penelitian pada studi kasus yang terjadi pada Tn. M didapatkan data sebagai berikut :
a. Klien mengatakan lemah
Penyakit Tuberkulosis Paru berdasarkan hasil penelitian studi kasus yang terjadi pada $\mathrm{Tn}$. $M$, didapatkan data adalah penyakit menular 
disebabkan Mycobacterium Tuberkulosis yang menyerang paru-paru. Pasien dengan Tuberkulosis Paru disertai batuk berdahak 2-3 minggu atau lebih. Batuk dapat diikuti dengan gejala tambahan yaitu badan lemas, nafsu makan menurun, berat badan menurun. (Maykel sondok,2016)

\section{b. Klien mengatakan mengalami mual}

Sesuai dengan teori yang dipaparkan menurut (Hidayat, Y, 2014) Mual pada pasien TB Paru disebabkan adanya iritasi lambung. Iritasi ini terjadi karena erusif dinding mukosa lambung akibat dari efek pemberian obat-obatan. Pada hasil yang saya dapatkan klien saya mengkomsumsi obat OAT jenis 2 FDC yaitu terdiri dari $150 \mathrm{mg}$ isoniazid dan $150 \mathrm{mg}$ rifampisi. Efek samping dari obat ini adalah mengalami mual muntah, kehilangan nafsu makan, nyeri ulu hati dan sakit perut.

Menurut (Kemenkes RI, 2017) bahwa munculnya efek mual, kurang nafsu makan disebabkan oleh obat Rifampisin dimana fungsinya adalah obat antibiotik yang digunakan untuk mengobati infeksi akibat bakteri. Efek samping berupa tidak adanya nafsu makan juga ditemukan pada penderita TB Paru. Penanganan yang dilakukan yaitu dengan memberikan vitamin B compleks, menganjurkan untuk minum susu dan dianjurkan untuk meminum obatnya di malam hari sebelum tidur.

\section{c. Klien mengatakan kekurangan nafsu makan}

Salah satu faktor yang mempengaruhi nafsu makan yaitu mual muntah, efek samping obat kurangnya asupan makan sehingga asam lambung naik dan batuk darah (Maykel sondok, 2016)

\section{d. Klien mengalami penurunan berat badan secara drastis}

Salah satu faktor yang mempengaruhi terjadinya penyakit Tuberkulosis Paru adalah status gizi. Dan adapun beberapa faktor yang berhubungan dengan status gizi pada pasien TB Paru yaitu kecukupan energi dan protein, perilaku klien terhadap makanan dan kesehatan, lama menderita TB Paru, infeksi TB mengakibatkan penurunan asupan dan malabsorbsi nutrisi serta perubahan metabolisme tubuh sehingga terjadi proses penurunan massa otot dan lemak, sehingga berat badan mengalami penurunan yang sangat drastis. (Elsa puspita, 2016)

\section{Diagnosa keperawatan}

Diagnosa keperawatan yang diangkat pada studi kasus Tn. M dengan Tuberkulosis Paru adalah Nutrisi kurang dari kebutuhan berhubungan dengan intake yang tidak adekuat dan diprioritaskan terhadap judul yang diteliti serta diagnosa diatas merupakan diagnosa yang paling sering dialami oleh Tuberkulosis Paru.

Menurut Wilkinson \& Judith,2016 batasan karakteristik dalam diagnosis ketidakseimbangan nutrisi kurang dari kebutuhan tubuh adalah kehilangan berat badan, menolak makan, membran mukosa pucat, dan sebagainya. Dari batasan karakteristik tersebut Tn. M mendapatkan gejala yang sama seperti kehilangan berat badan, membran mukosa pucat. Dari tanda dan gejala yang terjadi pada Tn.M disimpulkan bahwa klien mengalami kekurangan nutrisi.

\section{Intervensi}

Adapun intervensi yang dapat muncul berdasarkan diagnosa yang didapatkan pada Tn.M adalah ketidakseimbangan nutrisi kurang dari kebutuhan tubuh berhubungan dengan intake yang tidak adekuat.

a. Kaji status nutrisi klien, bagaimana turgor kulitnya, integritas mukosa oral, kemampuan menelan.

Menurut (Kozier, Erb, Berman, \& Synder,2010) pengkajian nutrisi adalah untuk mengidentifikasikan klien yang berisiko mengalami nutrisi dan mereka yang memiliki status nutrisi yang buruk.

b. Kaji tanda-tanda vital

Untuk mengetahui keadaan umum klien menurut (Bare \& Smeltezer, 2011), perawat dengan cermat memantau tanda- tanda vital dengan menilai fungsi tubuh yang paling benar dasar seperti tekanan darah, nadi, suhu, dan pernafasan.

c. Kaji pola makan klien

Menurut Surya, darma (2012) yang menjelaskan bahwa gizi cukup serta istirahat yang penuh pada penderita TB Paru ini dianjurkan. Hal ini memperkuat sistem pertahanan tubuh sehingga kuman TB Paru tidak ada lagi ditubuh. Makanan yang mengandung protein tinggi seperti telur, susu dan makanan yang cukup tinggi kadar proteinnya yang sangat diperlukan.

d. Timbang berat badan

Menurut Rahma (2014) berat badan dipakai sebagai indikator terbaik untuk mengetahui keadaan gizi kurang objektif dan dapat diulangi, dapat digunakan timbangan apa saja, relatif murah, mudah dan tidak memerlukan waktu. Berat badan harus dimonitoring agar memberikan informasi yang mementingkan intervensi gizi yang sedetail mungkin guna mengatasi kecenderungan penurunan atau penambahan berat badan yang tidak dikehendaki.

e. Anjurkan pasien makan dalam porsi sedikit tapi sering

Menurut (Bare \& Smeltezer, 2011) rencana tentang nutrisi yang memungkinkan makan sering dengan jumlah kecil mungkin diperlukan suplemen nutrisi cair, seperti ensure dan isocal, dapat membantu dalam memenuhi kebutuhan kalori dan dasar. 
f. Ajarkan perawatan mulut sebelum makan dan sesudah makan

Menurut (Saputra, 2013) perawatan mulut itu sangat penting, karena untuk perawatan mulut klien dapat mempengaruhi nafsu makan dan selera makan pasien.

g. Jelaskan pentingnya masukan nutrisi Menurut Himpunan Dokter Paru Indonesia (2017) saat tubuh terkena bakteri maka tubuh akan mengalami perlawanan dengan mempersiapkan pasukan baru yaitu mengaktifkan sistem kekbalan tubuh namun tanpa diberikan bekal nutrisi yang baik, pasukan perlawanan dalam tubuh akan melemah dan kemudian dapat membuat kondisi penderita TB Paru makin memburuk. Untuk itu nutrisi pada pasien TB harus terpenuhi.

h. Kolaborasi dengan ahli gizi untuk menetapkan komposisi dan diet yang tepat Menurut (Arsin,A;, Wahiduddin;,Ansar,J, 2012) hal ini perlu dilakukan untuk mengetahui barapa kebutuhan gizi pasien seperti, protein, lemak, vitamin, dan asupan nutrisi yang lainnya. Dan menurut (Bare \& Smeltezer, 2011) perawat bekerja secara kolaborasi dengan ahli gizi, dokter, pekerja sosial, dan pasienuntuk mengidentifikasi strategi memastikan masukan nutrisi yang adekuat dan untuk memastikan ketersediaan makanan yang bernutrisi.

i. Kolaborasi dengan tim medis pemberian obat multivitamin

Menurut penelitian (Lazulfa, 2016) pemberian obat OAT dan suplemen secara teratur menjadi trending dalam program peningkatan gizi agar dapat meningkatkan nilai IMT penderita Tuberkulosis Paru sehingga penderita dapat memperoleh percepatan menuju masa kesembuhan.

j. Berikan dukungan kepada klien jika dia mampu melakukan program nutrisi dengan benar

Menurut Qamariatun \& Darliana (2016), ada dukungan dari keluarga dengan pemenuhan nutrisi pada pasien TB Paru, dan keluarga diharapkan dapat meningkatkan dukungan keluarga khususnya dukungan sosial dan tambahan dalam pemenuhan nutrisi klien TB Paru dan bagi tenaga kesehatan umum diharapkan dapat memberikan informasi kepada keluarga terkait pemenuhan nutrisi yang tepat pada pasien TB untuk mempercepat proses penyembuhan.

\section{Implementasi}

Implementasi dilakukan sesuai dengan perencanaan keperawatan berdasarkan kondisi klien dan ketersediaan sarana dan prasarana serta kebijakan rumah sakit.

a. Mengkaji status nutrisi klien, bagaimana turgor kulitnya, integritas mukosa oral, kemampuan menelan.

Penting untuk mengetahui status nutrisi pasien, seperti mengetahui berat badannya, frekuensi makannya, untuk menentukan status nutrisi klien. Saat memberi makan klien, tanyakan urutan makanan yang ingin di makan klien, apabila klien tidak dapat melihat, katakan kepada klien mengenai makanan mana yang sedang diberikan, berikan waktu yang cukup bagi klien mengunyah dan menelan makanan sebelum suapan berikutnya. Juga berikan cairan sesuai permintaan atau jika klien tidak mampu berkomunikasi, tawarkan cairan setelah setiap tiga atau empat kali suapan makanan, sangat penting untuk menciptakan waktu yang menyenangkan, pilih topik percakapan yang menarik bagi klien yang ingin bercakap-cakap. (Elsa Puspita, 2016)

b. Mengkaji tanda-tanda vital

Keadaan umum pada klien dengan Tuberkulosis Paru dapat dilakukan secara selintas pandang dengan menilai keadaan fisik setiap bagian tubuh klien. Hasil pemeriksaan tanda-tanda vital pada klien dengan Tuberkulosis Paru biasanya didapatkan peningkatan suhu tubuh secara signifikan, frekuensi nafas meningkat apabila disertai sesak napas, denyut nadi biasanya meningkat seirama dengan peningkatan suhu tubuh dan frekuensi pernafasan, dan tekanan darah biasanya dengan adanya penyakit penyulit hipertensi. (Arif Muttaqin, 2009)

\section{Evaluasi}

Evaluasi merupakan tahap akhir dari proses keperawatan. Evaluasi dilakukan untuk menilai apakah tujuan yang ditetapkan dalam rencana keperawatan tercapai atau belum teratasi.

Dari diagnosa keperawatan yang penulis tegakkan di RSUD Labuang Baji Makassar, setelah melakukan tindakan keperawatan, evaluasi kasus pada pasien Tn.M teratasi yaitu :

Data subjektif : klien mengatakan sudah tidak sulit menelan, klien mengatakan nafsu makan sudah mulai membaik, klien mengatakan sudah mulai menghabiskan makanannya, klien mengatakan sudah melakukan makan sedikit tapi sering dengan frekuensi 4 sendok dalam 3x/hari, klien mengatakan sudah membersihkan mulutnya sebelum dan sesudah makan.

Data objektif : klien nampak tidak meringis lagi, klien nampak menghabiskan porsi makanannya, klien tidak lemas lagi, klien sudah mampu melakukan makan sedikit tapi sering, tidak mual dan tidak muntah, klien nampak membersihkan mulutnya. TTV TD: $120 / 80 \mathrm{mmHg}, \mathrm{N}: 80 \mathrm{x} / \mathrm{m}, \mathrm{S}: 36^{0} \mathrm{C}, \mathrm{P}: 20 \mathrm{x} / \mathrm{m}$. Assesment : masalah teratasi, planning : lanjutkan intervensi (1) kaji status nutrisi klien (2) kaji tandatanda vital klien (3) kaji pola makan klien (4) timbang berat badan (5) anjurkan klien makan sedikit tapi sering (6) ajarkan perawatan mulut sebelum dan sesudah makan (7) jelaskan pentingnya 
masukan nutrisi (8) kolaborasikan dengan ahli gizi untuk menetapkan komposisi diet yang tepat (9) kolaborasikan dengan tim medis pemberian obat multivitamin (10) berikan dukungan kepada klien jika dia mampu melakukan program nutrisi yang benar.

\section{KESIMPULAN}

Berdasarkan data yang diperoleh dapat diambil kesimpulan sebagai berikut :

1. Hasil pengkajian pada pasien Tuberkulosis Paru yang ditemui di Rumah Sakit Labuang Baji Makassar yaitu tidak nafsu makan, keadaan lemah karena penyakit Tuberkulosis Paru, nafsu makan kurang, klien mengatakan sulit menelan, klien meringis saat menelan, klien pusing jika bangun dari tempat tidur. Klien mengatakan terjadi penurunan berat badan, klien hanya menghabiskan 4 sendok makan dalam 3x/hari, klien mengatakan mual dan muntah, keadaan umum lemah, keadaan rambut klien kering, kusam dan mudah patah. Mata nampak anemis. Mukosa bibir pucat. Kuku klien mudah patah dan pucat. Berat badan klien $37 \mathrm{~kg}$ dan tinggi badan $164 \mathrm{~cm}$. TTV klien TD: 120/80 $\mathrm{mmHg}$, $\mathrm{N}: 80 \mathrm{x} / \mathrm{m}, \mathrm{S}: 36^{0} \mathrm{C}, \mathrm{P}: 18 \mathrm{x} / \mathrm{m}$.

2. Pada diagnosa keperawatan, masalah yang muncul pada Tn.M dengan pemenuhan kebutuhan nutrisi yaitu kekurangan nutrisi berhubungan dengan intake yang tidak adekuat.

3. Perencanaan disusun dengan teori yang berfokus pada mengkaji status nutrisi klien, bagaimana turgor kulitnya, kemampuan menelan, integritas mukosa oral, kaji tandatanda vital, kaji pola makan klien, timbang berat badan, anjurkan pasien makan sedikit tapi sering, ajarkan perawatan mulut sebelum dan sesudah makan, jelaskan pentingnya masukan nutrisi, kolaborasi dengan ahli gizi untuk menetapkan komposisi dan jenis diet yang tepat, kolaborasi dengan tim medis untuk memberikan terapi multivitamin, berikan dukungan kepada pasien jika dia mampu melakukan program nutrisi dengan benar.

4. Implementasi dilakukan sesuai dengan rencana atau intervensi keperawatan dengan memodifikasi sesuai kondisi pasien, hasil dari implementasi dapat mencapai tujuan tindakan keperawatan tersebut yaitu kebutuhan nutrisi klien terpenuhi.

5. Dalam evaluasi keperawatan, diagnosa keperawatan yang ditegakkan oleh penulis belum dapat teratasi dengan baik sesuai dengan hasil yang diharapkan, klien telah melakukan program diet yang baik tetapi belum ada perubahan dalam hal berat badan, hanya ada perubahan nafsu makan klien meningkat, mual dan muntah tidak ada

\section{SARAN} lain:

Adapun saran yang dapat diberikan, antara

1. Diharapkan kepada perawat dalam melaksanakan pengkajian pada klien, mengumpulkan data dengan menggunakan komunikasi terapeutik agar terbina hubungan saling percaya dengan klien maupun keluarga klien, baik dengan menggunakan tehnik wawancara, observasi, pemeriksaan fisik untuk mengumpulkan informasi yang dapat digunakan untuk menegakkan diagnosa keperawatan.

2. Diharapkan kepada perawat, dalam menegakkan diagnose keperawatan, hendaknya memperhatikan semua keluhan yang dialami oleh klien yang di dukung pula dengan hasil observasi dan pemeriksaan fisik serta penunjang lainnya.

3. Diharapkan kepada seluruh perawat, agar rencana tindakan yang akan diberikan kepada klien hendaknya disesuaikan dengan kondisi klien setiap hari berdasarkan hasil pengkajian yang telah di keluhkan.

4. Diharapkan kepada perawat, agar dalam melakukan implementasi keperawatan hendaknya memperhatikan dan memfokuskan asuhan keperawatan sesuai kebutuhan dan memberikan HE secara kontinyu khususnya yang terkait dengan pengobatan dan nutrisi klien dengan penyakit Tuberkulosis Paru.

5. Diharapkan kepada perawat, agar dalam pemberian asuhan keperawatan kepada klien agar melakukan evaluasi dan menilai sejauh mana perkembangan kondisi klien, apakah masalah teratasi atau tidak serta melakukan Discharge Planning pada pasien sebelum pulang atau berpindah ke ruang perawatan lainnya.

\section{DAFTAR PUSTAKA}

Ardiansyah, M. (2012). Medikal Bedah Untuk Mahasiswa. Jogjakarta: DIVA Press.

Dharma, K. K. (2011). Metodologi Penelitian Keperawatan Panduan Melaksanakan dan Menerapkan Hasil Penelitian. Jakarta: CV. Trans Info Medika.

Ernawati, K. (2018). Perbedaan Status Gizl Penderita Tuberkulosis Paru antara sebelum dan saat pengobatan Fase Lanjutan di Johar Baru, Jakarta Pusat. Jakarta: Majalah Kedokteran Bandung, Volume 50 No. 2, Juni 2018. 
Ernawati, S., \& Ahmad Rifai, A. K. (2012). Buku Ajar Konsep dan Aplikasi Keperawatan Dalam Pemenuhan Kebutuhan Dasar Manusia. Jakarta: CV. Trans Info Media.

Irman soematri, S. K. (2009). Asuhan Keperawatan pada klien dengan Gangguan Sistem Pernafasan, edisi 2. Jakarta: Salemba Medika.

Kozier, E. B. (2011). Buku Ajar Fundamental Keperawatan Konsep, Proses, \& Praktik. Jakarta: EGC Medica Publisher.

Nurarif, A. H., \& Kusuma, H. (2015). Aplikasi Asuhan Keperawatan Berdasarkan Diagnosa Medis dan Nanda Nic-Noc. Jogjakarta: Mediaction Jogja.

Oktaria, H. (2017). Gizi Pada Tuberkulosis Paru. RSUP Persahabatan dengan Intalasi Pelayanan Humas , 1.

Ramadhanti, D. (2016). Gambaran Pengetahuan Perawat tentang Manajemen Pelayanan HOSPITAL HOMECARE DI RSUD AL- IHSAN I- ihsan Provinsi Jawa Barat. Jawa Barat: Perpuspustakaan. upi.edu.

Saryono, A. T. (2011). Kebutuhan Dasar Manusia (KDM). Yogyakarta: Nuha Medika.

Somatri, I. (2009). Keperawatan Medikal Bedah : Asuhan Keperawatan pada Pasien Gangguan Sistem Pernafasan. Jakarta: Salemba Medika.

Wahid, A., \& Suprapto, I. (2013). Keperawatan Medikal Bedah, Asuhan Keperawatan Pada Gangguan Sistem Respirasi. Jakarta: CV. Trans Info Media.

Wartonah, T. (2015). Kebutuhan Dasar Manuisa dan Proses Keperawatan. Jakarta: Salemba Medika.

Wartonah, T. (2015). Kebutuhan Dasar Manusia dan Proses Keperawatan. Jakarta: Salemba Medika.

Wilkinson, J. M. (2016). Diagnosa Keperawatan : Diagnosis NANDA-1, Intervensi NIC, Hasil NOC, Edisi 10. Jakarta: Buku Kedokteran EGC.

Bare, B. G., \& Smeltezer, S. C. (2011). Buku Ajar Keperawatan Medikal Bedah. Jakarta: Buku Kedokteran EGC.

Heriana, P. (2014). Buku Ajar Kebutuhan Dasar Manusia. Tangerang Selatan: Binarupa Aksara. 